\title{
Effect of Feeding Peanut and Sesame Seeds on Bone of Rats Suffering from Osteoporosis
}

Nagibe, Ereny wilson

Faculty of Specific Education, Ain Shams University, Cairo, Egypt

\section{ABSTRACT:}

7 his study was carried out to determine the effect of two levels of peanut seeds (Arachis hypogaea) and sesame seeds (S. indicum) 1 on rats suffering from osteoporosis. Forty eight female rats weighting an average of $(200 \pm 10 \mathrm{~g})$ were used in this study. The rats were divided into two main groups. The first main group (6 rats) fed on basal diet as a (negative control group). The second main group (42 rats) received oral prednisone acetate (Glucocorticoid)(GC) daily for two weeks to induce osteoporosis, then the second main group divided into seven subgroups as follows: The first subgroup (6 rats) fed on basal diet as a (positive control group), the second and third subgroups fed on basal diet containing (5\% and 10\%) peanut seeds, respectively. The fourth and fifth subgroups fed on diet containing (5\% and 10\%) sesame seeds. The sixth and seventh subgroups fed on diet containing (5\% and $10 \%$ ) combination of Sesame and Peanut seeds. Sesame and peanut were added instead of corn starch. The results revealed that peanut seeds, sesame seeds, and combination especially 10\% improved the nutritional status, the kidney functions (uric acid, urea nitrogen and creatinine), level of calcium and phosphorus; femur bone calcium and femur bone phosphorus and bone mineral density (BMD), Bone Mineral Concentration (BMC) compared to the positive group. The study recommends eating (peanut, sesame) seeds and food rich in calcium that help in accelerating bone growth and decrease bone fracture incidence.

Key words: peanut seeds, sesame seeds, osteoporosis. 


\section{INTRODUCTION:}

Osteoporosis could be defined as a bone condition which characterized by low bone mass, increased fragility, decreased bone quality, and an increased fracture risk

(Vaytrisalova et al., 2007). Osteoporosis is a major public health problem (Riaz et al., 2008) which affects millions of people around the world and its frequency increases by age (Jalili et al., 2007). The perception that osteoporosis is an older person's disease is an erroneous one. Osteoporosis does not discriminate by age; in fact, it is a geriatric disease with an adolescent onset. During childhood and adolescence, much more bone is deposited than withdrawn, so the skeleton grows in both size and density. Up to 90 percent of peak bone mass is acquired by age 18 in girls and by age 20 in boys, which makes youth the best time to "invest" in one's bone health (Wahba et al., 2010). Currently, Osteoporosis among the top five conditions causing disability and prolonged hospital stay for older people

(Chan

2006).

Constructed bone mineral density charts for Egyptian women showed that they have a lower bone mineral density compared to their western counterparts (Sallam et al., 2006). According to the recent International Osteoporosis Foundation (IOF) report, 28.4\% of postmenopausal women in Egypt are estimated to have Osteoporosis (International osteoporosis foundation 2010) and (Taha 2011).

Peanuts are legumes and grow underground. Peanut is the fourth important oilseed crop of the world in production after soybean, cottonseed and rapeseed (Awad et al., 2000), (Arachis hypogaea) contained several active components including flavonoids, phenolic acids, phytosterols, alkaloids, and stilbenes (Lopes et al., 2011). They are similar to tree nuts in form and fat content. Approximately $60 \%$ of the energy in nuts and peanuts is derived from fat, and greater than $75 \%$ of this fat is unsaturated (USDA, 2009). Much of the health benefit attributed to nuts stems from the lipid lowering effects( Mukudden-Peterse et al.,2005) of their high unsaturated fatty acid profile as well as actions of other constituents like fiber, vitamin $\mathrm{E}$, and phytochemicals (Maguire et al.,2004). Peanuts 
are rich source of $\mathrm{Mg}$, foliate, fiber, atocopherol, $\mathrm{Cu}$, arginine and resveratrol (Edrees et al., 2008).

Sesame seed (Sesamum indicum L.), another widely consumed seed, is a good $\omega-6$ source. This cropped in both tropical and subtropical countries. India and China are the major producers accounting for $70 \%$ of world production (Arriel et al., 2005). Sesame oil has advantages over other vegetable oils owing to its high nutritional and therapeutic value. Sesame seeds, which are used in traditional Indian and Chinese medicine, contain $57 \%$ highly stable oil ( Reshma et al.,2010). Due to its high oxidative stability, sesame oil is added to margarines, salads, and frying oils (Yen and Lay 1990). Saturated fatty acid content in sesame oil is nearly $14 \%$, comparable to soy and corn oil. Oleic and linoleic acid levels are approximately $45 \%$, which is close to that found in corn, soy, and cottonseed oil (Embrapa 2001).

The present study was designed to evaluate the effects of two levels of peanuts seeds and sesame seeds on osteoporosis in female rats.

\section{MATERIALS \& METHODS}

\section{Materials:}

- Casein, vitamins, minerals, cellulose and choline chloride were obtained from ElGomhorya Company, Cairo, Egypt.Glucocorticoid (prednisone acetate) was obtained from pharmacy Cairo, Egypt.

- Normal female albino rats (Spraque- Dawely Strain) weighting 200 \pm 10 g. Were purchased from Helwan

- The basal diet was prepared according to (Reeves et al., 1993),

- Experimental Animals station

- Peanut and sesame seeds were obtained from agriculture research center Cairo, Egypt.

\section{Experimental design:}

Forty eight female rats (Sprague Dawley Strain) weighting an average $(200 \pm 10 \mathrm{~g})$ were housed in well aerated cages under hygienic condition and fed on basal control diet for one week for adaptation. After 
this period, the rats were divided into two main groups, as follows: The first main group (6 rats) fed on basal diet, as a negative control group. The second main group (42rats) fed on basal diet and oral prednisone acetate $\quad(4.5 \quad \mathrm{ml} / \mathrm{kg}$ body weight/day) for two weeks to induce osteoporosis according to (Liao et al., 2003). The second main group was divided into seven subgroups (6 rats each): Subgroup (1): fed on diet as a positive control group. Subgroups (2 and 3) fed on diets containing $5 \%$ and $10 \%$ peanut seeds, respectively. Subgroups (4 and 5) fed on diets containing $5 \%$ and $10 \%$ sesame seeds, respectively. Subgroups (6 and 7) fed on diets containing 5\% and $10 \%$ combination of (peanut and sesame seeds), respectively. Peanut and sesame were replacement corn starch.

During the experimental period (4 weeks), the diets consumed and body weights were recorded twice weekly according to (Chapman, et al., 1959). At the end of the experiment, the animals were fasted overnight, then the rats were anaesthetized and sacrificed, and blood samples were collected. Blood samples were centrifuged and the serum was separated to estimate some biochemical parameters. Kidney function according to the methods described by (Haisman and Muller 1977; Henry et al., 1974 and Larsen 1972), serum calcium according to (Baginski 1973), serum phosphorus by (Quinlan and Desesa 1955). Bones were removed from each rats, cleaned and weighted, half amount of separated bones were kept in frozen till analysis at $20^{\circ} \mathrm{C}$, while the other bones were fixed with $10 \%$ neutral formalin and decalcified with 5\% nitric acid solution for 1 day. The routine tissue processing for light microscopy was performed, and tissues were embedded in paraffin. Cross-sections of $5-\mu \mathrm{m}$ intervals were taken and stained with hematoxylin and eosin for measurement of femur bone thickness and Masson Trichrom for collagen fiber evaluation. Diaphyseal femur bone 
thickness was measured with ocular micrometer. Ten random areas were selected and average thickness was calculated for each femur (Comelekoglu et al., 2007). Calcium and phosphorus in femur bone of rats were determined according to the method described by (Muynck and Vanhaecke 2009). Bone Mineral Density (BMD) Bone Mineral Concentration (BMC) measured by Dual Energy x-ray absorptiometry (DEXA) in National Research Center, Osteoporosis Unit. The data obtained was analyzed statistically for standard deviation and one-way ANOVA test (Armitage and Berry 1987).

\section{RESULTS:}

Data presented in table (1) showed the effect of two levels from peanut, sesame seeds and their combination on the mean value of feed intake of rats suffering from osteoporosis. Feed intake of healthy rats (negative control group) fed on basal diet increased than that of osteoporotic rats (positive control group) (16.412vs.12.577 g/day/rat). Treating groups of rats suffering from osteoporosis with levels of (5\% and 10\%) peanut seeds, sesame seeds and their combination increased the mean value of feed intake, than that of the positive control group.

Result of feeding osteoporotic rats diets containing $5 \%$ and $10 \%$ (peanut and sesame) seeds and their combinations were presented in table (1). Using prednisone acetate to induce osteoporosis led to significant increase in BWG\%, as compared to the negative control group. The best results of $\mathrm{BWG} \%$ of all tested groups recorded for the group which treated with $10 \%$ combination of all seeds, followed by the groups treated with levels from seeds alone.

Effect of two levels from (peanut seeds, sesame seeds) and their combination on serum uric acid, urea nitrogen and creatinine $(\mathrm{mg} / \mathrm{dl})$ of rats suffering from osteoporosis in table(1) .The mean values of serum uric acid, urea nitrogen and creatinine of the positive control significantly increased than the negative control group .

The mean values of serum uric acid, urea nitrogen and creatinine decreased 
gradually with increasing the levels of seeds. The best results of serum uric acid, urea nitrogen and creatinine recorded for osteoporotic group treated with $10 \%$ combination of peanut seeds and sesame seeds, this treatment decreased the mean values of serum utric acid, urea nitrogen and creatinine.

Table(2)showed that the mean values of serum calcium and phosphorus, femur bone calcium and phosphorus, BMD and BMC of osteoporotic group (+ control) decreased significantly $\quad \mathrm{P}<0.05, \quad$ as compared to healthy rats fed basal diet. On the other hand, serum calcium and phosphorus, femur bone calcium and phosphorus increased gradually with increasing the level of seeds. The highest increase in serum calcium and phosphorus of femur bone calcium and phosphorus, recorded for the group treated with high level from combination of all seeds, this group increased the mean values of serum calcium.

\section{DISCUSSION:-}

In this study, body weight of peanut treated group was significantly lower in comparison to that of positive control group. Some investigators observed similar type of findings (Mattes, et al,.2008). It has been suggested that, peanut intake provides the body with high level of vitamin A, vitamin E, folate, calcium, magnesium, zinc, iron, and dietary fiber, and decrease the level of saturated fat, cholesterol, triglycerides and thus causes reduction of body weight (Alper and Mattes 2003).

Peanuts significantly reduce renal oxidative damage and increase nitric oxide levels. Thus, suppress toxin mediated enhancement of serum urea and creatinine levels (Wang,et al.,2011). Again, some other researchers suggested that the peanut keeps the serum creatinine level close to normal due to the ability of some antioxidant in peanut to scavenge free radicals generated by irradiation, which would otherwise cause kidney damage (Shimmi, et al, 2014 and Nath et al, 1994).

It has been reported that many health benefits are associated with consumption of peanuts including weight gain control (Alper, and Mattes 
2002) prevention against cardiovascular diseases (Feldman, 1999), protection against Alzheimer disease (Arlingten, 2002), and cancer inhibition. Benefits are mainly attributed to the fact that peanuts do not contain trans-fatty acids (Sanders, 2001) but they are rich in mono- and polyunsaturated fatty acids (Kris-Etherton, et al, 1999) ,micronutrients such as vitamin $\mathrm{E}$, folate, minerals(potassium, magnesium, and zinc), fibers and health promoting phytochemicals, particularly resveratrol ( Sanders et al., 2000) and other phenolic compounds.

Studies reported that, excess glucocorticoid causes muscular atrophy and a decreased rate of muscle protein synthesis and this lead to increase nitrogen compound that result from catabolism of muscle of protein. This compound may be heavy load on the kidney (Wolthers et al. 1997).

Other studies reported that dietary sesame seeds and its lignan increase both ascorbic acid concentration in some tissues and urinary excretion by stimulating biosynthesis in rats. Uchida et al, (2007) reported that dietary sesame seeds decreases urinary excretion of alpha and gamma tocopherol metabolites in rats.

Researches recommended to meals for osteoporosis. Milk and milk products are the representative sources of calcium supply and their absorbency is excellent and small fish that can be eaten whole, sesame seeds, and legumes in daily life (Titchenal and Dobbs, (2007).

Another study concluded that the $\mathrm{Ca}$ from sesame seeds and spinach does not cause an acute response in $\mathrm{Ca}$ metabolism. Also, that cheese could be a better dietary source of $\mathrm{Ca}$ than milk when the metabolic effects of the foods are considered ( Karkkainen et al, 1997).

Sesame is also a source of helpful biologically active components found in plant foods, such as phytochemicals and it is a functional food. Bioactive compounds and nutraceuticals in sesame could be used in the prevention, controlling and even the management of illnesses (Kanu 
et al., 2007)\&( Sacco et al ,2007).

\section{CONCLUSION:}

In summary, it appears that consumption of diets rich in peanut and sesame seeds improve kidney function and increase calcium and phosphorus thus reducing the incidences of osteoporosis in rats. Nutrition education program should be encouraged to inform the public about the protective effect of peanut and sesame seeds from osteoporosis.

\section{REFERENCES:}

\section{Alper CM and Mattes RD} (2002):

Effects of chronic peanut consumption on energy balance and hedonics. International Journal of Obesity 26, 1129-1137.

Alper CM and Mattes RD (2003):

Peanut Consumption

Improves Indices of

Cardiovascular Disease

Risk in Healthy Adults. J

Am Coll

Nutr.;22(2):133-41.

\section{Arlingten VA (2002):}

Antioxidants from Food Sources, like Peanuts and Peanut Butter, may protect against Alzheimer Disease. The Peanut-Institute, June 26, Press Release.

Armitage $\mathbf{P}$ and Berry $\mathbf{J}$ (1987):

Statistical Methods in Medical Research. Blackwell, Oxford, UK, PP. 93-212.

\section{Arriel NHC; Vieira DJ and} Firmino PT (2005):

Situação Atual E Perspectivas Da Cultura Do Gergelim No Brasil. Embrapa.

\section{Awad AB; Chan KC; Downie} AC and Fink CS (2000):

Peanuts as a source of bsitosterol, a sterol with anticancer properties. Nutrition and Cancer 36, 238-241.

Baginski ES (1973): 
Method of calcium

determination. Clin .chem. Acta, 46:49.

Chapman DG, Castilla $R$ and Campbell JA (1959):

Evaluation of protein in food. Determination of protein and food efficiency ratio. Can. J. Biochem. And Physil. 37: 679-686.

Chan MF (2006):

Osteoporosis prevention education programme for women. Journal of advanced nursing 54(2), 159-170.

\section{Comelekoglu U; Yalin S; Bagis} S; Ogenler O; Sahin NO; Yildiz Coskun AB; Hatungil R and Turac $A$ (2007):

Low-exposure cadmium is more toxic on osteoporotic rat femoral bone: Mechanical, biochemical, and histopathological evaluation. Ecotoxicology and Environmental Safety 66 (2): $267-271$.
Edrees GMF, El-Kholy WM, El-Habiby EM, El-Sherbiny SA (2008):

Protective Action of Peanut Oil in Rats Exposed to GammaRays. Belg J Zool;138(2):149-53.

Embrapa O (2001):

Agronegócio do gergelim no Brasil. Brasília: Ministério da Agricultura, Pecuária e Abastecimento,. p. 325.

Feldman EB (1999):

Assorted monounsaturated fatty acids promote healthy hearts. American Journal of Clinical Nutrition 70, 953-954.

Haisman $P$ and Muller BR (1977):

Quantitative enzymatic colorimetric determination of uric acid in serum. Clin. Chem. 26: 227. 
Henry JB; Todd M.K; Sanford LU and Davidsohn SG (1974):

Clinical diagnosis and measurement by laboratory methods 16th ed., W.B. Saunders and Co., Philadelphia, P.A. PP. 260.

International osteoporosis foundation (2010):

Available at

http://www.iofbonehealt

h.org/ (accessed 13 Feb. 2013).

Jalili Z; Nakhaee N; Askaril R; \& Sharifi V (2007):

Knowledge, attitude and preventive Practice of women concerning osteoporosis. Iranian Journal of Public Health $36,19-24$.

Karkkainen MUM; Wiersma JW; Amberg $L$ and Allardt C.J.E., (1997):

Postprandial parathyroid hormone response to four calcium rich foodstuffs. American Journal of clinical Nutrion.1997; 65(6): 1726-1730.

Kanu PJ; KeRui Z; Kanu JB; HuiMing $Z$; HaiFeng $Q$ and KeXue Z (2007):

Biologically active components and nutraceuticals in sesame and related products: a review and prospect. Trends in Food Science \& Technology. Elsevier, Amsterdam, Netherlands. 18: 12, 599-608. Many.

Kris-Etherton, PM; Pearson TA; Wan Y; Hargrove R I; Moriarty $K$ and Fishell $V$ (1999):

High monounsaturated fatty acid diets lower both plasma cholesterol and triacylglycerol concentrations. Am J Clin Nutr.70(6):1009-15.

Larsen K (1972):

Creatinine colormitric method.J. of Clin.Chem., 41:209. 
Liao JM; Li QN; Wu T; Hu B; Huang LF; Li ZH; Zhao WD; Zhang MC and Zhong SZ(2003):

Effects of prednisone on bone mineral density and biomechanical characteristics of the femora and lumbar vertebras in rats; 23(2):97-100.

Lopes RM; Agostini-Costa TDS; Gimenes MA \& Silveira D (2011):

Chemical composition and biological activities of Arachis species. Journal of agricultural and food chemistry, 59(9), 4321-4330.

Maguire LS; O'sullivan M; Galvin K; O'connor TP and O'brien, M (2004):

Fatty acid profile, tocopherol,squalene and phytosterol content of walnuts, almonds, peanuts, hazelnuts and macadamia nut. Int $\mathbf{J}$ Food Sci Nutr. 55(3)171178.
Mukudden-Peterse NJ; Oosthuizen W and Jerling JC (2005):

A systematic review of effects of nuts on blood lipid profile in humans. $\mathbf{J}$ Nutr. 135(9):2082-2089.

Muynck D and Vanhaecke F (2009):

Development of a method based on inductively coupled plasma-dynamic reaction cell-mass spectrometry for the simultaneous determination of phosphorus, calcium and strontium in bone and dental tissue. Spectrochimica Acta Part B: Atomic Spectroscopy 64(5): 408-415.

Mattes RD, Kris-Etherton PM and Foster GD (2008):

Impact of Peanuts and Tree Nuts on Body Weight and Healthy Weight Loss in Adults. J Nutr. 138(Suppl):S174145. 
Nath KA; Fischereder M; Hostetter TH (1994):

The Role of Oxidants in Progressive Renal Injury, Kidney International. 45(Suppl 43):S111-15.

Quinlan KP and Desesa M A (1955):

"Spectrophotometric

Determination of

Phosphorus as

Molybdovanadophosphoric Acid," Analytical Chemistry, Vol. 27,No.10,Pp. 1626-1629.

Reeves PG; Nielsen FH and Fahmy GC (1993):

AIN- 93 purified diets for laboratory rodient: Final report ofcommittee of reformulation of the AIN-76 A Rodent diet. J. Nutr. 123: 1939-51.

Reshma M V; Balachandran C; Arumughan C; Sunderasan A; Sukumaran D and Thomas $S$ (2010):

Extraction, separation and characterisation of sesame oil lignan for nutraceutical

applications. Food

Chemistry, v. 120, p. 1041-1046.

Riaz M; Patel J, Tariq M, Khan MS, Zuberi L, and Abid $\mathrm{N}(2008)$ :

Knowledge about Osteoporosis among healthy women attending a tertiary care hospital. Journal of the Pakistan Medical Association 58, 190-194.

Sacco S M; Power K A; Chen J; Ward W E and Thompson L U (2007):

Interaction of Sesame Seed and Tamoxifen on Tumor Growth and Bone Health in Athymic Mice. Exp. Biol. Med.; 232:754-761.

\section{Sanders TH (2001):}

Non-detectable levels of trans-fatty acids in peanut butter. Journal of Agricultural and Food Chemistry 49, 23492351. 
Sallam H; Galal AF and Rashed A (2006):

Menopause in Egypt: past and present perspectives. Climacteric 9(6): 421-429.

Sanders T.H; McMichael RW and Hendrix KW (2000):

Occurrence of resveratrol in edible peanuts, Journal of Agricultural and Food Chemistry 48, 12431246

Shimmi, SC, Parash MT;

Lazina $H$ and Akter $A$ P (2014):

Effect of Peanut

(Arachis hypogaea) on

Kidney in Rats, Delta

Med Col J. Jan;2(1):17-

21

Taha M (2011):

Prevalence

of

osteoporosis in Middle

East: systemic literature review. 10th ECOO, April 2011. Available at http://www.scribd.com/d oc (accessed 20 June 2012).

Titchenal CA and Dobbs J (2007):

A system to assess the quality of food sources of calcium. Journal of food composition and analysis. 2007; 20(8): 717-724.

Vaytrisalova M; Kubena A; Vleek V; Palicka T; Hala T and Pavelka K (2007):

Knowledge of osteoporosis correlated with hormone therapy use and health status. Maturitas 56(1): 21-29.

Uchida T; Ichikawa T; Abe C; Yamashita $K$ and Ikeda S(2007):

Dietary sesame seed decreases urinary excretion of alpha and gamma-tocopherol metabolites in rats. Journal of Nutritional Science and

Vitaminology. 2007; 53(4): 372-37. 
USDA (2009):

United

Department

Agriculture,

Agricultural

Zugriff am, 1.

Wahba SA; Abd El-Shaheed A; Tawheed MS; Mekkawy AA and Arrafa AM (2010):

Osteoporosis knowledge, beliefs, and behaviors among Egyptian female students. Journal of the Arab Society for Medical Research 5(2): 173-180.

\section{Wang M; Zhou X and Chu Y} (2011):

Effects of Peanut Shell

Extract on Rats with

Acute Renal Failure.

Remote Sensing,

Environment and

Transportation

Engineering (RSETE),

International Conference.

2011;8264-67.
Wolthers T; Grofite T; Jorgensen JO and Vilstrup $\mathrm{H}$ (1997):

Growth hormone prevents prednisoloneinduced increase in functional hepatic nitrogen clearance in normal man. J. Hepattol. 7(5): 789-795.

\section{Yen GC and Lay S H (1990):}

Oxidative stability of instant noodles fried with sesame oil-vegetable oil blends. Journal of Chinese Agriculture Chemical Society, n. 2, p.196-201. 
Table (1):-Effect of peanut seeds and sesame seeds on feed intake, Body weight gain\% and kidney functions of rats suffering from osteoporosis.

\begin{tabular}{|c|c|c|c|c|c|c|c|c|c|}
\hline \multicolumn{2}{|c|}{ Groups } & $\begin{array}{c}(-v e) \\
\text { Control }\end{array}$ & $\begin{array}{c}\text { (+ve) } \\
\text { Control }\end{array}$ & $\begin{array}{c}5 \% \\
\text { peanut } \\
\text { seeds } \\
\text { (PS). }\end{array}$ & $\begin{array}{c}10 \% \\
\text { peanut } \\
\text { seeds } \\
(\mathrm{PS}) .\end{array}$ & $\begin{array}{c}5 \% \\
\text { sesame } \\
\text { seeds } \\
(\mathrm{SS}) .\end{array}$ & $\begin{array}{c}10 \% \\
\text { sesame } \\
\text { seeds } \\
(\mathrm{SS}) .\end{array}$ & $\begin{array}{c}5 \% \\
\text { combinatio } \\
\text { n of }(P P, \\
\text { SS). }\end{array}$ & $\begin{array}{c}10 \% \\
\text { combinatio } \\
\text { n of (PP, } \\
\text { SS). }\end{array}$ \\
\hline \multicolumn{2}{|c|}{$\begin{array}{l}\text { Feed intake } \\
\text { (g/day/rat) }\end{array}$} & $\begin{array}{c}16.412 \pm \\
0.773^{\mathrm{a}}\end{array}$ & $\begin{array}{c}12.577 \pm \\
0.836^{\mathrm{e}}\end{array}$ & $\begin{array}{c}13.773 \pm \\
0.599^{\mathrm{b}}\end{array}$ & $\begin{array}{c}14.439 \pm \\
1.0731^{\mathrm{bc}}\end{array}$ & $\begin{array}{l}13.509 \pm \\
0.958^{\mathrm{e}}\end{array}$ & $\begin{array}{c}14.085 \pm \\
0.312^{\mathrm{a}}\end{array}$ & $\begin{array}{l}13.956 \pm \\
0.037^{\mathrm{de}}\end{array}$ & $\begin{array}{c}14.543 \pm \\
0.254^{\mathrm{a}} \\
\end{array}$ \\
\hline \multicolumn{2}{|c|}{$\begin{array}{l}\text { Body weight } \\
\text { gain } \%\end{array}$} & $\begin{array}{c}32.078 \pm \\
2.273^{\mathrm{a}}\end{array}$ & $\begin{array}{c}33.118 \pm \\
5.585^{\mathrm{e}}\end{array}$ & $\begin{array}{l}27.465 \pm \\
5.117^{\mathrm{de}}\end{array}$ & $\begin{array}{c}18.49 \pm \\
6.251^{\mathrm{bc}}\end{array}$ & $\begin{array}{c}29.824 \pm \\
3.124^{\mathrm{e}}\end{array}$ & $\begin{array}{l}21.407 \pm \\
8.085^{\mathrm{cd}}\end{array}$ & $\begin{array}{l}21.701 \pm \\
8.913^{\mathrm{cd}}\end{array}$ & $\begin{array}{l}16.325 \pm \\
4.958^{\mathrm{b}}\end{array}$ \\
\hline \multirow{3}{*}{$\frac{\sigma}{000}$} & Uric acid & $\begin{array}{l}1.510 \pm \\
0.026^{\mathrm{g}}\end{array}$ & $\begin{array}{l}2.475 \pm \\
0.061^{\mathrm{a}}\end{array}$ & $\begin{array}{l}2.081 \pm \\
0.042^{c}\end{array}$ & $\begin{array}{c}1.717 \pm \\
0.0324^{\mathrm{de}}\end{array}$ & $\begin{array}{l}2.140 \pm \\
0.051^{b}\end{array}$ & $\begin{array}{l}1.832 \pm \\
0.031^{d}\end{array}$ & $\begin{array}{l}1.934 \pm \\
0.043^{\mathrm{de}}\end{array}$ & $\begin{array}{l}1.602 \pm \\
0.027^{f}\end{array}$ \\
\hline & $\begin{array}{l}\text { Urea } \\
\text { nitrogen }\end{array}$ & $\begin{array}{c}32.909 \pm \\
1.306^{\mathrm{g}}\end{array}$ & $\begin{array}{c}57.987 \pm \\
3.412^{\mathrm{a}}\end{array}$ & $\begin{array}{l}48.779 \pm \\
2.015^{\mathrm{b}}\end{array}$ & $\begin{array}{l}37.738 \pm \\
1.486^{\mathrm{e}}\end{array}$ & $\begin{array}{l}51.001 \pm \\
2.671^{\mathrm{b}}\end{array}$ & $\begin{array}{l}39.029 \pm \\
1.663^{\text {de }}\end{array}$ & $\begin{array}{l}42.776 \pm \\
2.370^{\mathrm{d}}\end{array}$ & $\begin{array}{l}34.078 \pm \\
1.854^{\mathrm{g} \mathrm{f}}\end{array}$ \\
\hline & $\begin{array}{l}\text { Creatinin } \\
\mathrm{e}\end{array}$ & $\begin{array}{l}0.607 \pm \\
0.018^{\mathrm{g}}\end{array}$ & $\begin{array}{l}1.234 \pm \\
0.049^{\mathrm{a}}\end{array}$ & $\begin{array}{l}0.983 \pm \\
0.048^{c}\end{array}$ & $\begin{array}{c}0.891 \pm \\
0.056^{\mathrm{de}}\end{array}$ & $\begin{array}{l}1.036 \pm \\
0.074^{\mathrm{b}}\end{array}$ & $\begin{array}{c}0.886 \pm \\
0.021 \mathrm{de}\end{array}$ & $\begin{array}{l}0.812 \pm \\
0.052^{d}\end{array}$ & $\begin{array}{l}0.765 \pm \\
0.047^{f}\end{array}$ \\
\hline
\end{tabular}

- Values are expressed as mean \pm SD.- Significant at $p<0.05$ using one way ANOVA test.

- Values which have different letters in each column differ significantly, while those with similar letters are not significant 
Table (2): Effect of peanut seeds and sesame seeds on calcium, phosphorus, femur bone calcium, Femur bone phosphorus, BMD and BMC of rats suffering from osteoporosis.

\begin{tabular}{|c|c|c|c|c|c|c|c|c|c|}
\hline Par & Groups & $\begin{array}{l}\text { Contro } \\
\text { l (-ve) }\end{array}$ & $\begin{array}{l}\text { Contro } \\
\text { l (+ve) }\end{array}$ & $\begin{array}{c}5 \% \\
\text { peanut } \\
\text { seeds } \\
(\mathrm{pS}) .\end{array}$ & $\begin{array}{c}10 \% \\
\text { peanut } \\
\text { seeds } \\
(\mathrm{pS}) .\end{array}$ & $\begin{array}{c}5 \% \\
\text { sesame } \\
\text { seeds } \\
(\text { SS) }\end{array}$ & $\begin{array}{c}10 \% \\
\text { sesame } \\
\text { seeds } \\
(\mathrm{SS})\end{array}$ & $\begin{array}{c}5 \% \\
\text { combinati } \\
\text { on of ,PS } \\
\text { and SS. }\end{array}$ & $\begin{array}{c}10 \% \\
\text { combinati } \\
\text { on of ,PS } \\
\text { and SS. }\end{array}$ \\
\hline \multirow{2}{*}{$\stackrel{\widehat{\Xi}}{\stackrel{\Xi}{\Xi}}$} & Calcium & $\begin{array}{l}4.476 \pm \\
0.121^{a}\end{array}$ & $\begin{array}{l}2.921 \pm \\
0.063^{i}\end{array}$ & $\begin{array}{l}2.969 \pm \\
0.085^{\mathrm{g}}\end{array}$ & $\begin{array}{c}3.987 \pm \\
0.086\end{array}$ & $\begin{array}{l}2.964 \pm \\
0.096^{h}\end{array}$ & $\begin{array}{l}3.891 \pm \\
0.072^{f}\end{array}$ & $\begin{array}{l}3.048 \pm \\
0.069^{\mathrm{cd}}\end{array}$ & $\begin{array}{l}4.247 \pm \\
0.058^{b}\end{array}$ \\
\hline & Phos & $\begin{array}{l}3.572 \pm \\
0.049^{\mathrm{a}}\end{array}$ & $\begin{array}{l}1.828 \pm \\
0.068^{\mathrm{e}}\end{array}$ & $\begin{array}{c}2.076 \pm \\
0.105^{\mathrm{cd}}\end{array}$ & $\begin{array}{l}2.877 \pm \\
0.115^{c}\end{array}$ & $\begin{array}{l}2.159 \pm \\
0.088^{d}\end{array}$ & $\begin{array}{l}3.117 \pm \\
0.113^{c}\end{array}$ & $\begin{array}{l}2.996 \pm \\
0.083^{\mathrm{b}}\end{array}$ & $\begin{array}{l}3.388 \pm \\
0.075\end{array}$ \\
\hline \multirow{2}{*}{$\sum_{\Xi}^{00}$} & $\begin{array}{l}\text { Femu } \\
\text { Calcil }\end{array}$ & $\begin{array}{c}46.566 \pm \\
1.738^{\mathrm{a}}\end{array}$ & $\begin{array}{r}27.3 \\
2.37\end{array}$ & $\begin{array}{c}33.772 \pm \\
1.753^{d}\end{array}$ & $\begin{array}{c}39.995 \pm \\
0.485^{\mathrm{c}}\end{array}$ & $\begin{array}{c}32.585 \pm \\
0.465^{\mathrm{c}}\end{array}$ & $\begin{array}{l}38.559 \pm \\
0.476^{\text {de }}\end{array}$ & $\begin{array}{c}38.996 \pm \\
0.881^{\mathrm{c}}\end{array}$ & $\begin{array}{c}43.213 \pm \\
0.883^{\mathrm{b}}\end{array}$ \\
\hline & $\begin{array}{l}\text { Femur bone } \\
\text { phosphorus }\end{array}$ & $\begin{array}{c}93.715 \\
\pm 2.230^{\mathrm{a}}\end{array}$ & $\begin{array}{c}57.404 \pm \\
2.378^{\mathrm{i}}\end{array}$ & $\begin{array}{c}67.842 \pm \\
0.824^{\mathrm{e}}\end{array}$ & $\begin{array}{c}74.463 \pm \\
0.615^{\mathrm{c}}\end{array}$ & $\begin{array}{c}63.178 \pm \\
0.743^{\mathrm{h}}\end{array}$ & $\begin{array}{c}73.283 \pm \\
0.175^{\mathrm{f}}\end{array}$ & $\begin{array}{l}73.101 \pm \\
0.702^{d}\end{array}$ & $\begin{array}{l}82.834 \pm \\
1.127^{\mathrm{b}}\end{array}$ \\
\hline \multirow{2}{*}{ छै } & BMD & $\begin{array}{c}0.169 \pm \\
0.0041^{a}\end{array}$ & $\begin{array}{c}0.068 \pm \\
0.0037^{\mathrm{g}}\end{array}$ & $\begin{array}{c}0.108 \pm \\
0.0037^{\mathrm{e}}\end{array}$ & $\begin{array}{c}0.138 \pm \\
0.0035 \mathrm{c}\end{array}$ & $\begin{array}{l}0.099 \pm \\
0.0049^{f}\end{array}$ & $\begin{array}{c}0.130 \pm \\
0.0025^{\mathrm{e}}\end{array}$ & $\begin{array}{c}0.121 \pm \\
0.0026^{\mathrm{d}}\end{array}$ & $\begin{array}{c}0.149 \pm \\
0.0061^{\mathrm{b}}\end{array}$ \\
\hline & $\mathrm{BMC}$ & $\begin{array}{c}0.099 \pm \\
0.0023^{\mathrm{a}}\end{array}$ & $\begin{array}{c}0.036 \pm \\
0.0037^{\mathrm{g}}\end{array}$ & $\begin{array}{c}0.059 \pm \\
0.0026^{\mathrm{e}}\end{array}$ & $\begin{array}{l}0.076 \pm \\
0.022^{b}\end{array}$ & $\begin{array}{c}0.058 \pm \\
0.0015^{\mathrm{f}}\end{array}$ & $\begin{array}{c}0.069 \pm \\
0.0017^{\mathrm{d}}\end{array}$ & $\begin{array}{c}0.071 \pm \\
0.017^{\mathrm{bc}}\end{array}$ & $\begin{array}{l}0.087 \pm \\
0.004^{\mathrm{a}}\end{array}$ \\
\hline
\end{tabular}

- Values are expressed as mean \pm SD.- Significant at $p<0.05$ using one way ANOVA test.

- Values which have different letters in each column differ significantly, while those with similar letters are not significant 
Effect of Feeding Peanut and Sesame Seeds on Bone of Rats Suffering from Osteoporosis

Nagibe, Ereny Wilson

\section{Histopathological study of Bone:}

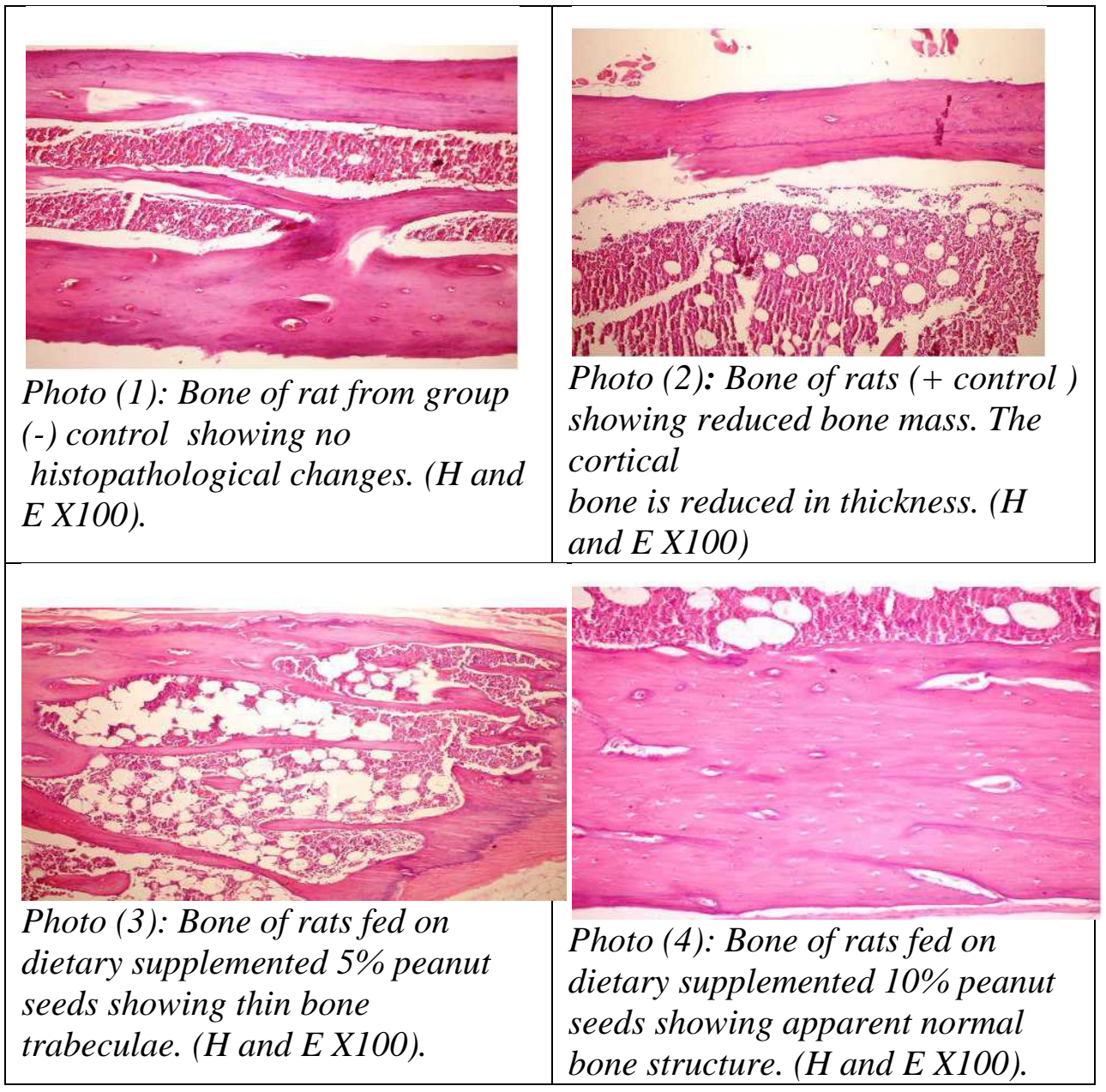


Effect of Feeding Peanut and Sesame Seeds on Bone of Rats Suffering from Osteoporosis

Nagibe, Ereny Wilson

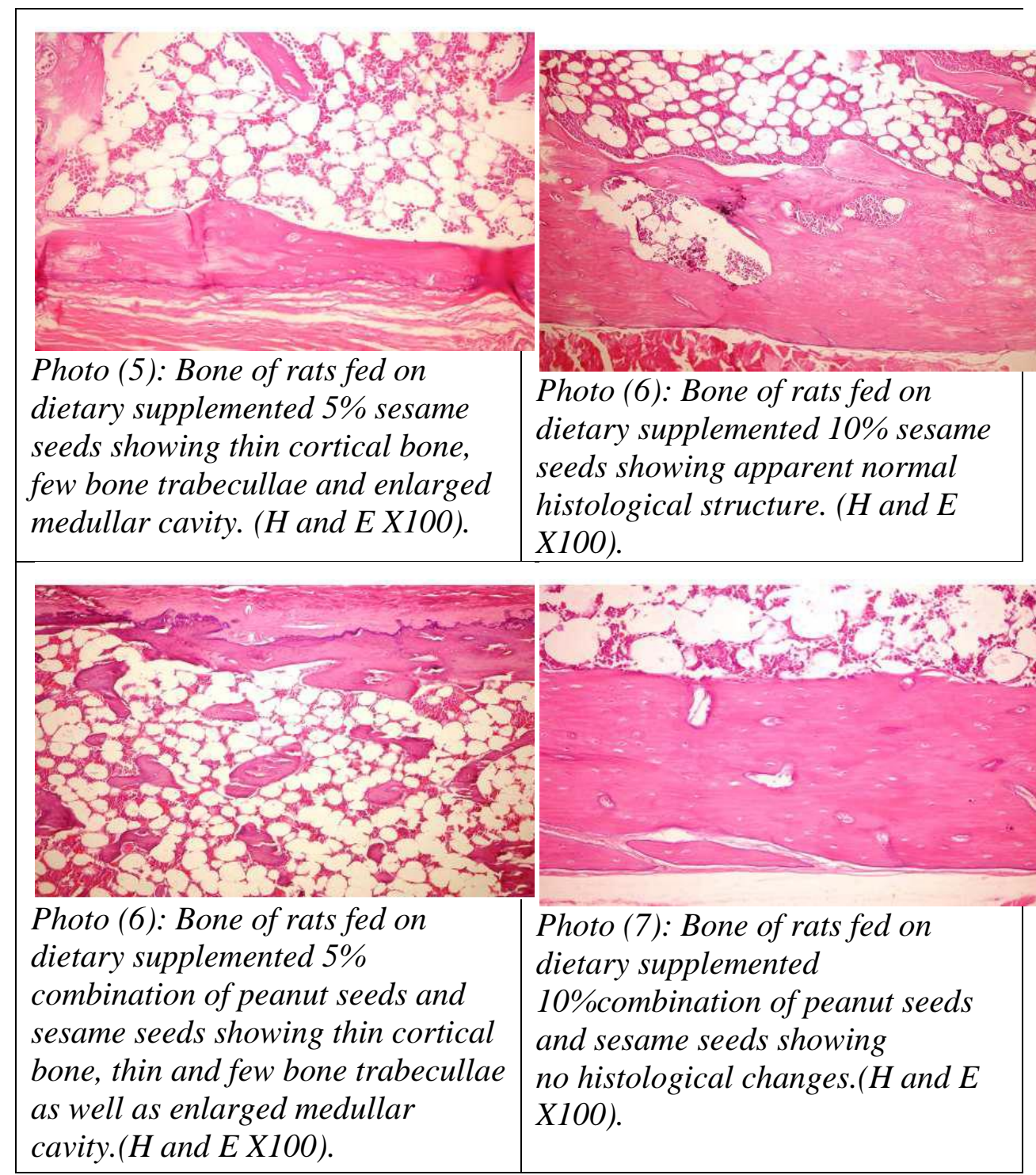




\section{تاثير تناول بذورالفول السودانى و السمسم على

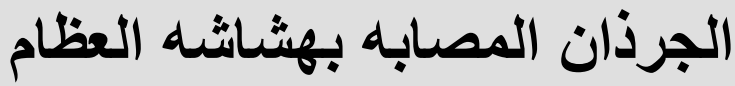 \\ ايرينى ولسن نجيب}

قسم التغذيه و علوم الاطعمه بالاقتصـاد المنزلى ـ كلية التربيه النو عيه- جامعة عين شمس

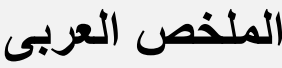

اجريت هذه الدراسه لمعرفة تاثير بذور الفول السودانى و السمسم على الجرذان

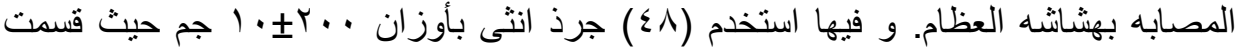

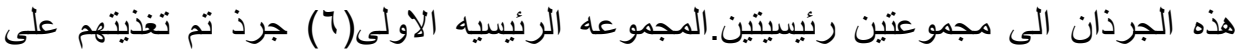

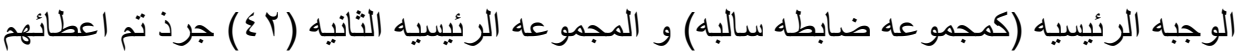

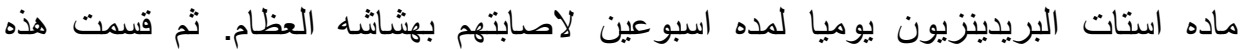

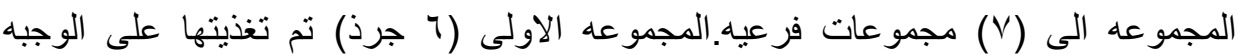

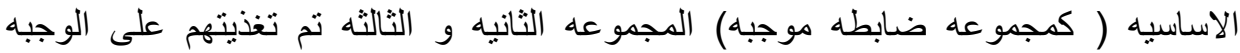
الاساسيه مضاف لها نسب ( • (\%) من بذور الفول السودانى. المجمو عه الر ابعه و الخامسه

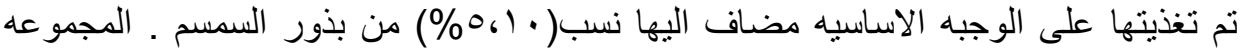

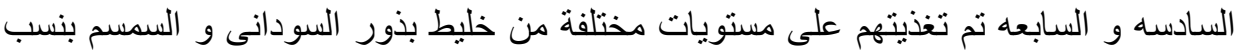

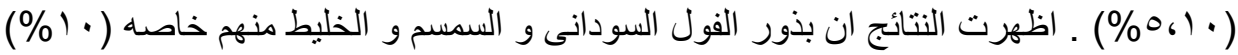

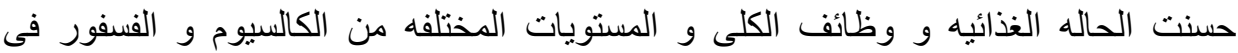
العظام و حسنت من كثافه المعادن فى العظام ومحتوى المعادن فى العظام و محتوى عظام


نتصح بتناول الفول السودانى و السمسم و الاطعمه ذات المحتوى العالى من الكالسيوم ليساعد دئه على زياده معدل نمو العظام و يقلل من معدل ترقق العظام . الكلمات المفتاحيه: بذور الفول السودانى، بذور السمسم، هشاثـه العظام . 